DOI: 10.33310/2078-2128-2021-21-2-5-11

UDC: 159.946 .3

\author{
IRYNA SAVENKOVA, \\ Doctor of Psychological Sciences, Professor \\ ORCID ID 0000-0003-0081-9297 \\ E-mail: savenkova-1966@ukr.net
}

V. O. Sukhomlynskyi National University of Mykolaiv, Mykolaiv, Ukraine

\title{
TIME FACTOR AND PSYCHODIAGNOSTICS PROBLEM OF GASTROENTEROLOGICAL DISORDERS
}

\begin{abstract}
The study found out the dependence of the manifestation of symptoms of chronic non-communicable diseases of the digestive system on the duration of a person's own unit of time. It was identified that individual age points of exacerbations of chronic non-communicable diseases of the gastrointestinal tract are consistent with the duration of the individual's own biological cycle.

Method. In each patient examined by the chronometric test method the " $\tau$ type" was determined, for which the classical method of reproducing intervals with a duration of $t_{Q}=2,3,4,5 \mathrm{c}$ was used, which were set by the experimenter and reproduced by the surveyed using an electronic chronoscope with an accuracy of $0.001 \mathrm{c}$. Results. It was identified that individual age points of exacerbations of chronic non-communicable diseases of the gastrointestinal tract are consistent with the duration of the individual's own biological cycle.

Keywords: large biological cycle of the individual, " $\tau$-type", dominant disease, phase singularity, biological cycle.
\end{abstract}

Introduction. Understanding the psychosomatic unity of a person, accepting and implementing a holistic approach to the patient are current tasks of modern medicine. The thesis "to treat not a disease, but a patient" defined the practice of outstanding doctors already in the last century. The principle of the individual approach to treatment requires comprehensive consideration of the psychological characteristics of each individual, and it's not by chance that it's the basis for solving an important problem of modern medicine - the chronization of non-communicable diseases.

Extremely relevant in this context is the issue of chronization of the non-infectious process in childhood in the absence of congenital pathology of this body system. Between 12 and 20 children per 1,000 children aged 7 to 14 years suffer from chronic non-communicable diseases. Among them, according to the World Health Organization, $40 \%$ are diseases of the urinary system, $20 \%$ of the respiratory system, $20 \%$ of the cardiovascular system, and $10 \%$ of the digestive system. And this is in the absence of congenital pathology and timely prevention of the disease twice a year (spring - autumn), as well as when using well-developed dispensary observation schemes. At the same time, it is known that the chronization of many non-communicable diseases in childhood often leads to disability in adulthood. Therefore, there is a need to use scientific and diagnostic tools to predict the exacerbation of this chronic disease and timely prevent the disease, taking into account traditional medical prevention schemes.
The aim of the researchis to substantiate individually determined patterns and mechanisms of time experience in a contingent of children suffering from chronic non-communicable diseases of the gastrointestinal tract.

\section{Research objectives.}

1. Select the individual's own unit of time suffering from chronic non-communicable diseases of the digestive system in the duration that they experience.

2. Compare the duration of the own unit of time with the psychosymptomatics of chronic non-communicable diseases of the digestive system.

3. To find out the relationship and relation of different cycles of experiencing duration to periods of exacerbation, convalescence, and remission of chronic non-communicable diseases of the gastrointestinal tract.

4. To study the degree of subjective severity of pain and clinical manifestations of chronic non-communicable diseases of the digestive system in typological groups of a continuous spectrum of " $\tau$-types".

Author's idea. The cause of the disease, that is, functional disorders of organs and systems of the body that lead to disruption of the body in general, it's impossible to understand without knowing the psychological characteristics of the patient's personality, and therefore adequately predict the course of a particular disease. L. G. Terletska writes that" ultimate cause, which gives animpetus to the 
appearance of various diseases, is most often found in human psychology ".

Our approach to the study of the etiology, pathogenesis, and clinical manifestations of the disease is carried out from a new position that fully takes into account the laws of time experience (D. G. Elkin, B. I. Tsukanov). Based on the" $\tau$-type", which determines the value of each individual's own unit of time, it's possible to assign a particular subject to a group with its dominant disease with high accuracy. The latter primarily include chronic non-communicable diseases $[1 ; 6 ; 10 ; 11]$. Such differentiation is too important in medicine, because it indicates the predominance of a particular disease and when and in what form it can occur in a particular individual. Using the "C-periodicity", it's possible to accurately determine the main parameters of an individual's own psychological clock, including calculating age-related critical points at which the dominant disease manifests itself in an acute form [13]. This approach can significantly strengthen the potential of Preventive Medicine. According to L. G. Terletska, it is "health psychology as a new branch of knowledge about a person that is directly related to the emergence of Preventive Medicine".

At the same time, the questions of localization of symptoms of each individual nosologicalform of chronic non-communicable diseases of the digestive system in the typological group of the continuous spectrum of " $\tau$-types" and the degree of severity of clinical manifestations of the disease in children suffering from chronic non-communicable diseases of the gastrointestinal tract remain open in this problem field. Moreover, as far as we know, there is no classification of the degree of subjective severity of pain in chronic non-communicable diseases of the digestive system in medicine at all.

Highlighting previously unresolved parts of a common problem. The problem of dominant diseases, which include chronic non-communicable diseases, is far from being fully solved, since during the chronization of the process there are periods of exacerbation, convalescence (recovery) and remission (fading) of the disease, that is, the course of the disease has a time sweep and each of its periods manifests itself at a certain age, which medicine is now unable to explain.

Presentation of the main research material and the obtained scientific results of the study. Our task -to study symptoms localization of chronic non-communicable diseases of the digestive system in typological groups in children -was solved experimentally on a number of children aged 7 to 14 years. In other words, the study was conducted with children, both during the period of aggravation, and reconvaluation (recovery) and remission (attenua- tion) of the disease. A questionnaire was filled out for each person surveyed, which revealed the following: 1) the age of the child (indicating the number wheret ${ }_{Q}$ is the duration set by the experimenter, and $\tau_{s}$ is the duration reproduced by the subject. The reproduction of each time interval was repeated five times, and then the average value of each child's own time unit was calculated. A total of 300 children between 7 and 14 years of age participated in the study. A total of 80 children aged 7 to 14 years with chronic diseases of the gastrointestinal tract were examined, of which 39 children suffered from chronic gastritis, 9 from gastric ulcer, 12 from chronic cholecystitis, 11 from chronic pancreatitis, and 9 from biliary dyskinesia (BD). At the same time, among children with chronic gastritis, 23 children were at the acute stage and 16 were in remission.

Modern medicine prefers the infectious factor in the occurrence of ulcerative processes in the stomach. In other words, the Hp factor is a rod that has aphasia (the ability to enter the of years and months at the time of the examination); 2) the date, month, year of his birth; 3) the type of NCDs; 4) the subjective severity of pain and its forms; 5) the degree of subjective severity of pain on a scale: 1 point - "weak", 2 points - "dull", 3 points - "moderate", 4 points - "acute", 5 points - "unbearable"; 6) a table with the definition of t-own unit of time a child.

Method. In each patient examined by the chronometric test method [15, p. 35-45], the " $\tau$ - type" was determined, for which the classical method of reproducing intervals with a duration of $t_{Q}=2,3,4$, $5 \mathrm{c}$ was used, which were set by the experimenter and reproduced by the surveyed using an electronic chronoscope with an accuracy of $0.001 \mathrm{c}$. The individual value of " $\tau$-type" was calculated using the formula:

$$
\tau=\frac{\Sigma t s}{\Sigma t o},
$$

which determines the course of relapse processes of the disease. This explains the cumulative process of chronization of these diseases. Among the aggressive factors that contribute to stomach diseases, there are: a) hyper-production of hydrochloric acid b) action of pepsin; c) impairment of the motor function of the stomach; g) presence of non-steroidal and steroid hormones (corticosteroids) d) hyper-production of bile. However, a critical analysis of these data shows that these risk factors can explain the cause of approximately half of the occurrence and development of stomach diseases in the human population. $35 \%$ of the total number of individuals suffering from stomach diseases have a socalled asymptomatic form that leads to the devel- 
opment of the ulcerative process but is not accompanied by risk factors [7]. Today, gastroenterologists do not know propedeutically who may have a clinical form of stomach disease such as gastritis or ulcerative disease. The problem of stomach diseases is still far from its final solution. One of the reasons for this is the lack of study of two points concerning the very essence of the disease: first, stomach diseases are a non-infectious process that affects $20 \%$ of the child population; second, they act as chronic, that is, their development and course have a temporary organization, and their clinical forms such as gastritis and stomach ulcers are detected at a certain age. Since the number of people suffering from stomach diseases in the human population, according to World statistics, remains relatively constant, it's likely to assume that there are individuals (or a group of individuals) who "mostly" suffer from stomach diseases. If such personalities and groups of "predominants" of the gastric disease do exist, then the so-called Risk Factors of this disease in their initial forms can be easily detected in individuals of this psychotype long before their probable action.

The proper unit of time of the examined sick children for chronic gastritis and gastric ulcer is in the range of $1.0 \mathrm{~s}<\tau<1.1 \mathrm{~s}$, which corresponds to a group of individuals who are "dominated" by stomach diseases of the typological array of one of the five segments of the continuous spectrum of " $\tau$-types" [9]. In particular, it has been established that a large group of chronic diseases in childhood are those of organs involved in the digestion of food in the gastrointestinal tract. First of all, we are talking about cholecystitis, pancreatitis and biliary dyskinesia. In medical practice, there is a tendency of individuals to suffer from diseases of the gallbladder, pancreas and biliary tract, although there are still no means to predict a particular disease.

The proper unit of time in children suffering from chronic cholecystitis is in the range of $0.7 \mathrm{~s}<\tau<0.72 \mathrm{~s}$, pancreatitis $-0.73 \mathrm{~s}<\tau<0.75 \mathrm{~s}$ and BD $-0.7 \mathrm{~s}<\tau<0.8 \mathrm{~s}$, which corresponds to a group of individuals in whom liver and gallbladder diseases "predominate" [8].

According to Eysenck's indicators, individuals with their own unit $(\tau)$ in the range of $0.7 \mathrm{~s}<\tau<0.8 \mathrm{~s}$ suffering from liver and gallbladder diseases are characterized by high extraversion, stability, and arousal in them is twice as predominant as inhibition. In addition, they are purposeful and aggressive in behavior. Individuals with this" $\tau$-type "approach the category of "purely choleric". Individuals with their own time unit $(\tau)$ in the range of $1 \mathrm{~s}<\tau<1.1 \mathrm{~s}$ suffering from chronic stomach diseases are characterized by denominated introversion and stabili- ty, a high level of arousal and inhibition that balance each other, and their mobility is twice low, than in the" $\tau$-types " of other individuals. That is why they are calm, work productively in a familiar situation, and typologically they can be attributed to "purely phlegmatic" [12].

Therefore, for effective prevention in medicine, it is necessary to fully take into account the psychological individual characteristics of each individual prone to diseases of the gastrointestinal tract. This will where $\mathrm{T}$ is the individual's own unit of time, which plays the role of a "step" that measures the passage of time of each person's life from the moment of his birth. Based on the known range of values in the human population $(0.7 \mathrm{~s}<\tau<1.1)$ [2], it's easy to conclude that for each individual, the "Cmetric" is determined by the duration of its own unit of time. It's known,that in the middle of a large biological cycle, limited to points $1 /{ }_{4} \mathrm{C}$ and $3 /{ }_{4} \mathrm{C}$, a person is "on top", feels full of strength and energy. In the period starting from $3 / 4$ of the previous cycle and up to the end of $1 / 4$ of the next, the face experiences a deep decline and certain destructive changes are observed. At the point where the end and beginning of the two great biological cycles converge, the individual "dies and is reborn in a new way" spiritually filled [3].

Results of the study of the manifestation of " $\mathrm{C}$ metric" during chronic diseases of children show that the frequency of exacerbation of chronic diseases of the gastrointestinal tract is $1 /{ }_{2} \mathrm{C}$ and $1 /{ }_{4} \mathrm{C}$, and the degree of subjective severity of pain ranges from $0.7 \mathrm{~s}<\tau<0.8 \mathrm{~s}$ (from 4 to 7 points, i.e. acute and unbearable pain). Moreover, there is a clear progression of pain severity from $\tau=0.7 \mathrm{~s}$ to $\tau=0.8 \mathrm{~s}$. At the same time, the degree of subjective severity of pain in the range of $1 \mathrm{~s}<\tau<1.1 \mathrm{~s}$ is characterized as mild, dull, moderate pain (from 1 to 3 points). Here there is a gradual progression of pain severity from $\tau=1 \mathrm{~s}$ to $\tau=1.1 \mathrm{~s}$.

Discussion. "The perception of time, reflecting objective reality, allows a person to navigate in the external environment, and gives an objectively correct idea of it," D. G. Elkin noted [8]. Using the expression of M. Shaginyan regarding the fact that each individual has his own "little Chronos", B. I. Tsukanov adds "With its own speed of time flow and with its own time perspective" [21]. I. P. Pavlov considered the question of those processes that take place in the human brain under the conditions of perception of duration, speed and sequence and came to the conclusion that the "measure of time" in the nervous system is the change in arousal by inhibition [20]. The phenomenon of trace conditioned reflexes, which were established in the laboratory of I. P., is directly related to the question 
of time perception. Pavlov, by Pimenov and Grossman. I. P. Pavlov, considering the trace reflex as a reflex for time, tried to find a connection between individual differences in the development of conditioned reflexes for time with the type of nervous system. D. G. Elkin considered the dependence of the accuracy of reproduction of duration on the type of temperament [8]. He noted some differences in the accuracy of reproducing time intervals in choleric, sanguine, melancholic, phlegmatic people, but did not give a complete description of the attitude to the actual experience of time by representatives of these four typological groups. Bogoraz V. G. wrote that every living individual has his own time, that is, sanguine-one, phlegmatic - another, etc. [19]. In his opinion, although these differences are small, there is no complete coincidence. In the works of Tsukanova B. I. scientifically proved that representatives of different typological groups are not only characterized by "different times", but also there is a similarity of relations to the experience of time in individuals belonging to the same typological group, which indicates the presence of generalized profiles that are commensurate with the classical typology of temperaments. In general, it identifies and Famous time researchers (E. I. Govomakha, A. A. Kropin, P. Fress, D. G. Elkin [8]) noted that humanity in the process of reproduction has preserved itself within the stable boundaries of typological groups throughout the previous history. Therefore, individually determined features of the attitude to time were reflected in the activities of subjects, their philosophical generalizations, political views, and poetic works. According to I. G. Belyavsky [19], the analysis of such reflections makes it possible to reproduce quite clearly the individual originality of historical figures. P. Fress [18] notes that the conservative ideology was followed by subjects with an orientation to the past, and the radical ideology was followed by those who turned to the future. B. I. Tsukanov emphasizes that "a person builds his attitude to time on a historical and even cosmic scale, taking into account the life time of his carrier - an individual " [17]. Therefore, the scientist comes to the conclusion that there is no linear relationship between the profile of an individually determined attitude to time and the time of the individual. To overcome time, you need to, according to the expression of P. Fresco, to achieve the "wisdom of the old" and accept time as it is given to each of us - with its duration, lack, and unreliability [16]. Taking into account individual characteristics regarding the dynamics of time experience and generalized profiles of individuals, we will try to determine the criteria for the typology of dominant diseases.
Among chronic non-communicable diseases as dominant $[15 ; 14 ; 13]$, analyzes in detail five types of such profiles [15]. Largegroup consists of cardiovascular diseases, which are collectively called the number one disease of the XX century. If we consider the adult population of the Earth, then a quarter of it suffers from these diseases; they are the cause of every second death sentence of fate, every third disability [2]. Solving problems of prevention of cardiovascular diseases by influencing the corresponding risk factors can explain only half of the cases of occurrence and development of coronary heart disease in the human population [10]. In 30\% of the total number of individuals suffering from coronary heart disease, there is a so-called asymptomatic form, which causes an unexpected heart attack, because it is not accompanied by risk factors [9]. Today, cardiologists don't know who can have such a clinical form of coronary heart disease as myocardial infarction [8]. Therefore, an important point in the prevention of cardiovascular diseases is to take into account the psychological aspects of the prevention of these diseases, which were considered by V. Y. Alexandrova, E. A. Suslova, A. A. Alexandrov [1]. The works of B. I. Tsukanova are of great importance in creating a system of cardio prevention of the adult population [21].

Conclusions and prospects of further re-

\section{search:}

1. The results of the carried out research that the degree of subjective severity of pain in disorders "chronic non-communicable diseases" is consistent with the individual's own time unit in the typological group of the continuous spectrum of " $\tau$-types", that is, it has a clear age and typological localization.

2. Differentiation has been made between the subjectiveexpression of the pain response according to the " $\tau$-type" It's important in medicine because it allows the doctor to predict the degree of the disease in each individual patient when chronic non-communicable diseases worsen in ontogenesis and to prevent the disease on time.

3. Early prevention of a non-communicable disease will create conditions to prevent its exacerbation and help stop the chronization of the non-communicableprocess itself.

4. In an updated subject context, it's appropriate to direct further search to the study of the agreement between the subjective assessment (pain) and the objective characteristic of the patient's condition, primarily indicators of the respiratory system and cardiovascular system of the body. 


\section{Література:}

1. Andrushchenko T.A., Goncharov S.V., Dosenko V.E. Fiziologichnyi Zhurnal 2018;64(4):12-9. URL:https://doi. org/10.15407/fz64.04.012

2. Birren J.E. The psychology of ageing. Boston: Little, Brow Company 2014.

3. Brun R. General treatment of nevrosis. Springfield: Merriam-Webster 2016.

4. Desai G, Chaturvedi S.K. Do Diagnostic Criteria for Psychosomatic Research Explain Diagnosis of Medically Unexplained Somatic Symptoms? Psychotherapy and Psychosomatic 2016; 85: 121-2. URL:https://doi. org/10.1159/000441063 PMid:26807856

5. Ehrenwald H. Attempts to time perception of the unconscious ark. New York: Psychologie 2014.

6. Elkin D.G. Experiencing time. Doctoral thesis. Odessa: ONU imeni I.I. Mecnikova 1945.

7. Elkelboom E.M., Tak L.M., Roest A.M., Rosmalen J.G. A systematic review and meta - analysis of the percentage of revised diagnoses in functional somatic symptoms. Journal of Psychosomatic Research 2016; 88:60-7. URL:https://doi.org/10.1016/j.jpsychores.2016.07.001 PMid:27455914

8. Fava G.A., Cosci F., Sonino N. Current Psychosomatic Practice. Psychotherapy and Psychosomatics 2017; 86: 13-30. URL:URL:https://doi.org/10.1159/000448856 PMid:27884006

9. Fink P. Syndromes of bodily distress or functional somatic syndromes where are we heading. Journal of Psychosomatic Research 2017; 97:127-30. URL:https://doi.org/10.1016/j.jpsychores.2017.04.012 PMid:28606492

10. Henningsen P., Zipfel S., Sattel H., Creed F. Management of Functional Somatic Syndromes and Bodily Distress. Psychotherapy and Psychosomatics 2018; 87(1):12-31. URL: https://doi.org/10.1159/000484413 PMid:29306954

11. Kebrikov A.V. About time perception. Moscow: Vysshaya shkola 2013.

12. Savenkova I., Didukh, M., Mukhina, L., Litvinenko, I. Large biological cycle duration in patients with respiratory organs disorders. Electronic Journal of General Medicine. 2018; 15(6): em 83. doi:10.29333/ejgm / 99826.

URL:http://www.ejgm.co.uk/download/large-biological-cycle-duration-in-patients-with-respiratory-organsdisorders-7486.pdf

13. Savenkova I. Didukh, M., Chuhueva, I., Litvinenko, I. Chronopsychological mental development dysontogenesis prognosing in pre-school children. Electronic Journal of General Medicine. 2019; 16(2): em110. doi:10.29333/ ejgm/108595. URL: http://www.ejgm.co.uk/download/chronopsychological-mental-development-dysontogenesis-prognosing-in-pre-school-children-7513.pdf

14. Savenkova I., Didukh, M., Ruda, N., Hazratova, N. Differentiation of time characteristics in subjects with depressive states. Electronic Journal of General Medicine. Electronic Journal of General Medicine. 2019; 16(3): em 141. doi:10.29333/ejgm/109436. URL: http://www.ejgm.co.uk/download/differentiation-of-timecharacteristics-in-subjects-with-depressive-states-7544.pdf

15. Savenkova I., Didukh, M., Shevchenko, V., Venger A. The Study of Individuation Mechanisms and Factors. International Journal of Applied Exercise Physiology. 2019; Vol 8 (2.1). P. 374 - 381. doi: 1030472/ijaep. v8i2.1.566. URL: http://ijaep.com/Journal/vol.8.2.1.pdf

16. Savenkova I., Didukh, M., Hazratova, N., Snyadanko, I. Psychosomatic unity of human from the position of chronopsycholoqy on the example of ischemic disorders and heart diseases. Electronic Journal of General Medicine. 2019; 16(6): em157. doi:10.29333/ejgm /114263. URL: http://www.ejgm.co.uk/download/ psychosomatic-unity-of-human-from-the-position-of-chronopsychology-on-the-example-of-ischemic-7563.pdf

17. Savenkova I., Didukh, M., Litvinenko, I., Mukhina, L., Venger A., Shevchenko, V. Successful athlete's chronopsychological profile. Psychology and Education 2019. 56 (3-4), P.120 - 134. URL: http://www. psychologyandeducation.net/pae/successful-athletes-chronopsychological-profile-irina-savenkova-mykoladidukh-iryna-lytvinenko-lyudmila-mukhina-anna-venger-vladimir-schevchenko/

18. Savenkova I., Didukh, M., Litvinenko, I., Chuhueva, I. Time factor in psychological profiling of information technology specialists for future career success. Journal of Environmental Treament Techniques. 2019; Special Issue on Environment, Management and Economy, Pages: 1041 - 1045. URL: http://www.jett.dormaj.com/ docs/Volume $7 /$ special\%20issue/Time $\% 20$ Factor $\% 20$ in $\% 20$ Psychological $\% 20$ Profiling $\% 20$ of $\% 20$ Information\%20Technology\%20Specialists\%20for\%20Future\%20Career\%20Success.pdf

19. Savenkova I., Didukh M., Khazratova N., Voitsekhovska O. Chronopsychological forecast of nefrourological diseases. EurAsian Journal of BioSciences, 14, 2411-2415 (2020)/ URL: http://www.ejobios.org/download/ chronopsychological-forecast-of-nefrourological-diseases-7796.pdf

20. Didukh, M., Savenkova, I., Kuznetsova, O., Litvinenko, I., Oleksyuk, O. Features of display of anxiety of children suffering from psychosomatic diseases. Journal of Environmental Treatment Techniques, 2020, 8(4), c. 15161520. URL: http://www.jett.dormaj.com/docs/Volume8/Issue\%204/Features\%20of\%20Display\%20of\%20 Anxiety\%20of\%20Children\%20Suffering\%20from\%20Psychosomatic\%20Diseases.pdf

21. Tsukanov B.Y. Time in human psyche. Odesa: Astroprint 2000. 


\section{References:}

1. Andrushchenko T.A., (2018). Goncharov S.V., Dosenko V.E. Fiziologichnyi Zhurnal 64(4):12-9. URL: https://doi. org/10.15407/fz64.04.012

2. Birren J.E. (2014). The psychology of ageing. Boston: Little, Brow Company.

3. Brun R. (2016). General treatment of nevrosis. Springfield: Merriam-Webster.

4. Desai G, Chaturvedi SK. (2016). Do Diagnostic Criteria for Psychosomatic Research Explain Diagnosis of Medically Unexplained Somatic Symptoms? Psychotherapy and Psychosomatic; 85:121-2. URL:https://doi. org/10.1159/000441063 PMid:26807856

5. Ehrenwald H. (2014). Attempts to time perception of the unconscious ark. New York: Psychologie.

6. Elkin D.G. (1945). Experiencing time. Doctoral thesis. Odessa: ONU imeni I.I. Mecnikova.

7. Elkelboom E.M., Tak L.M., Roest A.M., Rosmalen J.G. (2016). A systematic review and meta - analysis of the percentage of revised diagnoses in functional somatic symptoms. Journal of Psychosomatic Research ; 88:60-7. URL:https://doi.org/10.1016/j.jpsychores.2016.07.001 PMid:27455914

8. Fava G.A., Cosci F., Sonino N. (2017). Current Psychosomatic Practice. Psychotherapy and Psychosomatics ; 86:13-30. URL:https://doi.org/10.1159/000448856 PMid:27884006

9. Fink P. (2017). Syndromes of bodily distress or functional somatic syndromes where are we heading. Journal of Psychosomatic Research ;97:127-30. URL:https://doi.org/10.1016/j.jpsychores.2017.04.012 PMid:28606492

10. Henningsen P, Zipfel S, Sattel H, Creed F. (2018). Management of Functional Somatic Syndromes and Bodily Distress. Psychotherapy and Psychosomatics ;87(1):12-31. URL:https://doi.org/10.1159/000484413 PMid:29306954

11. Kebrikov A.V. (2013). About time perception. Moscow: Vysshaya shkola.

12. Savenkova I., Didukh, M., Mukhina, L., Litvinenko, I. (2018). Large biological cycle duration in patients with respiratory organs disorders. Electronic Journal of General Medicine.; 15(6): em 83. doi:10.29333/ejgm / 99826. URL: http://www.ejgm.co.uk/download/large-biological-cycle-duration-in-patients-with-respiratoryorgans-disorders-7486.pdf

13. Savenkova I. Didukh, M., Chuhueva, I., Litvinenko, I. (2019). Chronopsychological mental development dysontogenesis prognosing in pre-school children. Electronic Journal of General Medicine; 16(2): em110. doi:10.29333/ejgm/108595. URL: http://www.ejgm.co.uk/download/chronopsychological-mental-development-dysontogenesis-prognosing-in-pre-school-children-7513.pdf

14. Savenkova I., Didukh, M., Ruda, N., Hazratova, N. (2019). Differentiation of time characteristics in subjects with depressive states. Electronic Journal of General Medicine. Electronic Journal of General Medicine. ; 16(3): em 141. doi:10.29333/ejgm/109436. URL: http://www.ejgm.co.uk/download/differentiation-of-time-characteristics-in-subjects-with-depressive-states-7544.pdf

15. Savenkova I., Didukh, M.,Shevchenko, V., Venger A. (2019). The Study of Individuation Mechanisms and Factors. International Journal of Applied Exercise Physiology. Vol 8 (2.1). P. 374 - 381.doi: 1030472/ijaep.v8i2.1.566. URL: http://ijaep.com/Journal/vol.8.2.1.pdf

16. Savenkova I., Didukh, M., Hazratova, N., Snyadanko, I. (2019). Psychosomatic unity of human from the position of chronopsycholoqy on the example of ischemic disorders and heart diseases. Electronic Journal of General Medicine. 2019; 16(6): em157. doi:10.29333/ejgm /114263. URL: http://www.ejgm.co.uk/download/ psychosomatic-unity-of-human-from-the-position-of-chronopsychology-on-the-example-of-ischemic-7563.pdf

17. Savenkova I., Didukh, M., Litvinenko, I., Mukhina, L., Venger A., Shevchenko, V. (2019). Successful athlete's chronopsychological profile. Psychology and Education 56 (3-4), P.120 - 134. URL: http://www. psychologyandeducation.net/pae/successful-athletes-chronopsychological-profile-irina-savenkova-mykoladidukh-iryna-ly tvinenko-lyudmila-mukhina-anna-venger-vladimir-schevchenko/

18. Savenkova I., Didukh, M., Litvinenko, I., Chuhueva, I. (2019). Time factor in psychological profiling of information technology specialists for future career success. Journal of Environmental Treament Techniques. ; Special Issue on Environment, Management and Economy, Pages: 1041 - 1045. URL: http://www.jett.dormaj.com/docs/ Volume7/special\%20issue/Time\%20Factor\%20in\%20Psychological\%20Profiling\%20of\%20Information\%20 Technology\%20Specialists\%20for\%20Future\%20Career\%20Success.pdf

19. SavenkovaI.,Didukh M., Khazratova N.,Voitsekhovska O.(2020). Chronopsychological forecast of nefrourological diseases. EurAsian Journal of BioSciences, 14, 2411-2415.URL: http://www.ejobios.org/download/ chronopsychological-forecast-of-nefrourological-diseases-7796.pdf

20. Didukh, M., Savenkova, I., Kuznetsova, O., Litvinenko, I., Oleksyuk, O. (2020). Features of display of anxiety of children suffering from psychosomatic diseases. Journal of Environmental Treatment Techniques, 8(4), c. 1516-1520. URL: http://www.jett.dormaj.com/docs/Volume8/Issue\%204/Features\%20of\%20Display\%20 of $\% 20$ Anxiety $\% 20$ of $\% 20$ Children $\% 20$ Suffering $\% 20$ from $\% 20$ Psychosomatic\%20Diseases.pdf

21. Tsukanov B.Y. (2000). Time in human psyche. Odesa: Astroprint. 
Ірина Савенкова,

доктор психологічних наук, професор,

Миколаївський національний університет імені В. О. Сухомлинського, Миколаїв, Україна

\section{ФАКТОР ЧАСУ І ПСИХОДІАГНОСТИКА ПРОБЛЕМ}

\section{ГАСТРОЕНТЕРОЛОГІЧНИХ РОЗЛАДІВ}

Анотація. У статті представлені теоретичні засади та результати експериментального методу дослідження особистостей з гастроентерологічними розладами з позиції їх часової спрямованості та тривалості біологічного циклу життя індивіда. Життєвий шлях і особливості перебігу хвороби у будь-якого хворого підпорядковується певному хронотипу. Вплив особливостей переживання людиною часових відрізків на особливості перебігу внутрішніх процесів можна використовувати у якості критерію, який вказує на особливості перебігу хвороби та періоди її виникнення і загострення. А також, з урахуванням тривалості біологічного циклу життя індивіда можна підрахувати періоди «підйому» та «спаду» в житті людини, і водночас, це дає можливість пояснити особливості психічного стану особистості в певні періоди життя. Також врахування одиниці переживання часу виступає об'єктивним показником індивідуальних відмінностей, які мають суттєве відбиття у всіх життєвих циклах особистості, від динаміки перебігу внутрішніх процесів у організмі до психологічних процесів і динаміки особистості, її розвитку, активності. Все вище зазначене вказує на те, що у галузі практичної психології окреслюється потреба в методі, який у найкращий спосіб відповідав би характеристикам переживання часу людини, яким виступає метод хронометрування.

У дослідженні з'ясовувалась залежність прояву симптомів хронічних неінфекційних захворювань травної системи від тривалості одиниці часу, яку людина має. Метод. У кожного обстеженого пацієнта хронометричним методом тесту було визначено „тип $\tau$ ”, для якого був використаний класичний метод відтворення інтервалів тривалістю: $t=2,3,4,5$ с, які були встановлені експериментатором і відтворені обстеженим за допомогою електронного хроноскопу з точністю до 0,001 с. Результат. Було виявлено, що окремі вікові точки загострення хронічних неінфекційних захворювань шлунково-кишкового тракту відповідають тривалості власного біологічного циклу життя людини.

Ключові слова: великий біологічний цикл особистості, “т-тип”, домінантна хвороба, фазова особливість, біологічний цикл. 